\title{
Collection of available
} solar process heat related national and trans-national research and funding programs

Subtask E "Guideline to Market"

Deliverable Report D.E1

IEA SHC TASK 64 | IEA SolarPACES Task IV | Solar Process Heat 


\section{Collection of available solar process heat related national and trans-national research and funding programs}

This is a report from SHC Task 64 I SolarPACES Task IV: Solar Process Heat and work performed in Subtask E: Guideline to Market

Author/s: Peter Nitz, Jürgen Fluch

Date April 28, 2021

Report number: Task 64/IV, Deliverable Report D.E1

The contents of this report do not necessarily reflect the viewpoints or policies of the International Energy Agency (IEA) or its member countries, the IEA Solar Heating and Cooling Technology Collaboration Programme (SHC TCP) members or the participating researchers. 


\section{Solar Heating and Cooling Technology Collaboration Programme (IEA SHC)}

The Solar Heating and Cooling Technology Collaboration Programme was founded in 1977 as one of the first multilateral technology initiatives (“Implementing Agreements") of the International Energy Agency.

Our mission is "Through multi-disciplinary international collaborative research and knowledge exchange, as well as market and policy recommendations, the IEA SHC will work to increase the deployment rate of solar heating and cooling systems by breaking down the technical and non-technical barriers."

IEA SHC members carry out cooperative research, development, demonstrations, and exchanges of information through Tasks (projects) on solar heating and cooling components and systems and their application to advance the deployment and research and development activities in the field of solar heating and cooling.

Our focus areas, with the associated Tasks in parenthesis, include:

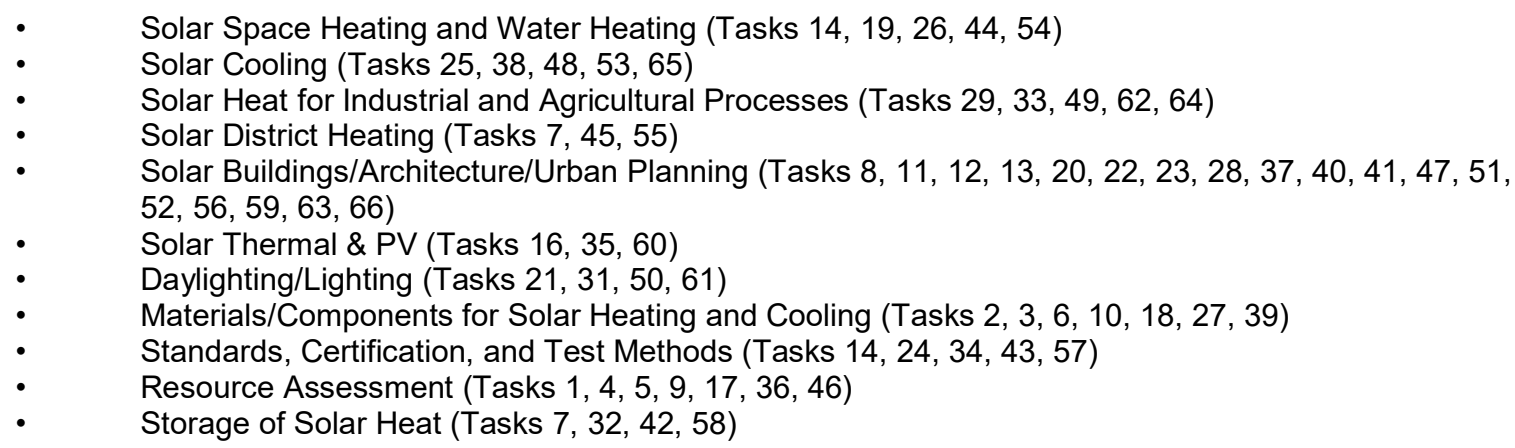

In addition to our Task work, other activities of the IEA SHC include our:

$>$ SHC Solar Academy

$>$ Solar Heat Worldwide, annual statics report

$>$ SHC International Conference

\section{Our members}

$\begin{array}{lll}\text { Australia } & \text { European Copper Institute } & \text { SACREEE } \\ \text { Austria } & \text { France } & \text { Slovakia } \\ \text { Belgium } & \text { Germany } & \text { South Africa } \\ \text { Canada } & \text { International Solar Energy } & \text { Spain } \\ \text { CCREEE } & \text { Society } & \text { Sweden } \\ \text { China } & \text { Italy } & \text { Switzerland } \\ \text { Denmark } & \text { Netherlands } & \text { Turkey } \\ \text { EACREEE } & \text { Norway } & \text { United Kingdom } \\ \text { ECREEE } & \text { Portugal } & \\ \text { European Commission } & \text { RCREEE } & \end{array}$

For more information on the IEA SHC work, including many free publications, please visit www.iea-shc.org 


\section{Solar Power and Chemical Energy Systems Technology Collaboration Programme (IEA SolarPACES)}

The SolarPACES Technology Collaboration Programme was founded in 1977 as one of the first multilateral technology initiatives ("Implementing Agreements") of the International Energy Agency.

Our mission is to facilitate technology development, market deployment and energy partnerships for sustainable, reliable, efficient and cost-competitive concentrating solar power technologies by providing leadership as the international network of independent experts.

To realize this mission, SolarPACES coordinates and advances concentrating solar technology research, by focusing on the next generation of technologies, by providing information and recommendations to policy makers and by organizing international conferences, workshops, reports and task meetings.

Our focus areas are organized in six tasks:

- Task I: Solar Thermal Electric Systems

- Task II: Solar Chemistry Research

- Task III: Solar Technology and Advanced Applications

- Task IV: Solar Heat Integration in Industrial Processes

- Task V: Solar Resource for High Penetration and Large Scale Applications

- Task VI: Solar Energy and Water Processes and Applications

In addition to our Task work, other activities of the IEA SolarPACES include:

$>$ SolarPACES International Conference.

$>$ Review of CSP market and cost data with the International Renewable Energy Agency (IRENA).

$>$ Joint project on solar resource for high penetration and large scale applications in collaboration with the TCP on Photovoltaic Power Systems (PVPS TCP).

$>$ Project in solar process heat in collaboration with the TCP on Solar Heating and Cooling (SHC TCP).

\section{Our members}

$\begin{array}{lll}\text { Australia } & \text { Austria } & \text { Brazil } \\ \text { Chile } & \text { China } & \text { European Commission } \\ \text { France } & \text { Germany } & \text { Greece } \\ \text { Israel } & \text { Italy } & \text { Mexico } \\ \text { Morocco } & \text { Namibia } & \text { Republic of Korea } \\ \text { South Africa } & \text { Spain } & \text { Switzerland } \\ \text { United Arab Emirates } & \text { United States of America }\end{array}$

For more information on the IEA SolarPACES work, including many free publications, please visit: 


\section{Contents}

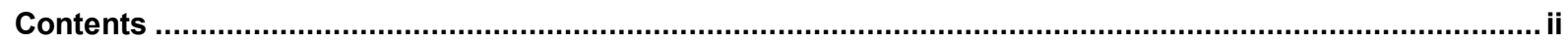

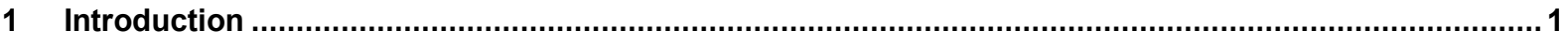

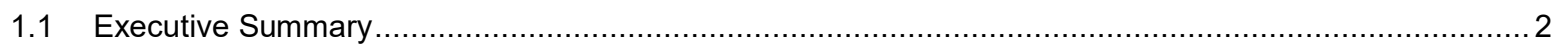

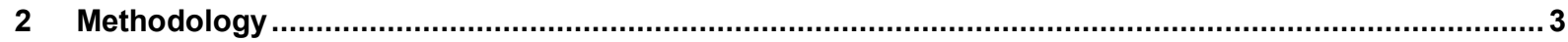

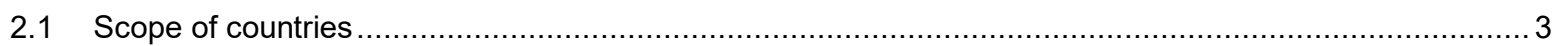

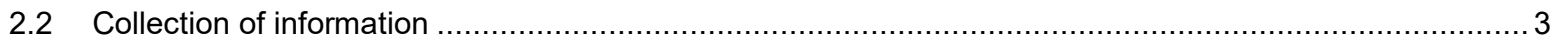

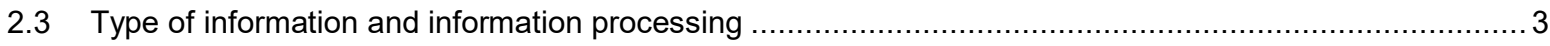

3 Collection of available research and funding/incentive programs...............................................

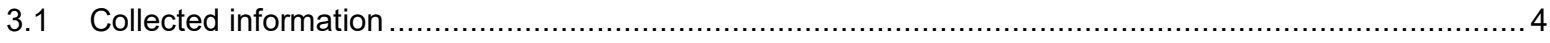

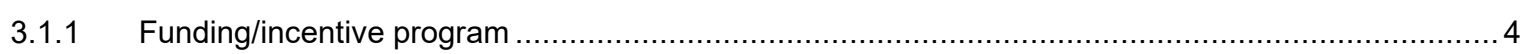

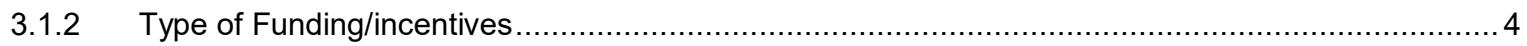

3.2 Overview on available funding programs for SHIP related RTD and funding/incentive programs for

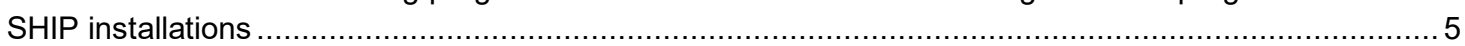

3.3 Overview on available types of funding/incentive programs for SHIP installations ............................ 6

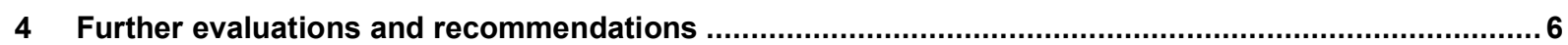

4.1 Relation between available programs and status of SHIP implementation ................................... 6

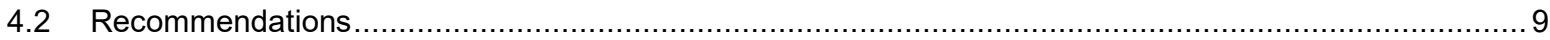

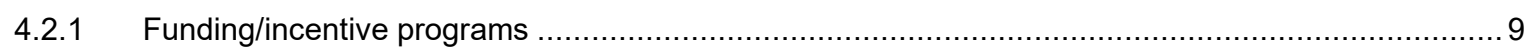

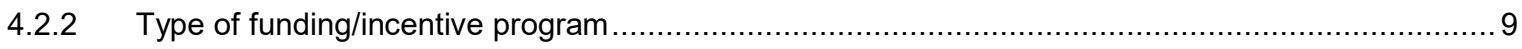

5 ANNEX: Detailed results and detailed list of available SHIP RTD funding and SHIP incentives.......... 10

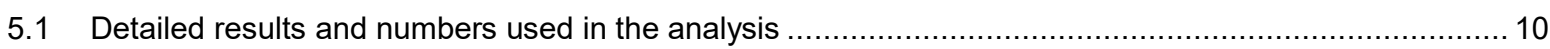

5.2 SHIP related research funding and funding/incentives programs for SHIP installations ..................... 12 


\section{Introduction}

Within Task 64/IV Solar Process Heat, Subtask E "Guideline to Market" is aiming to support a wider penetration of solar thermal technologies in the supply of heating (and cooling) in industry, demonstrating Solar Heat for Industrial Processes (SHIP) to be an important contribution to the decarbonisation of the industrial sector. This requires not only to overcome technical and/or technological barriers, but it is crucial to also address nontechnical barriers. Whereas well suited system integration strategies, design tools, standardized procedures or modular components are all in all paramount for the development of reliable and prompt "off the shelve" solutions, experience shows that often non-technological barriers might have a critical role in the decision making process. Above all, competitiveness and investment/financing related barriers prove in many cases to be the bottleneck for the adoption of solar thermal technologies in the industrial framework.

Thus, Subtask $E$ aims at drafting the guidelines of a market approach more prone to be successful among industrial end-users. Closing the circle of strategies tackling technical and non-technical barriers to market penetration, in this subtask Solar Heat for Industrial Processes (SHIP) is to be delivered to industrial end-users as a simple, reliable, innovative, affordable and profitable technological solution for the decarbonization of heating (and cooling) supply to industry. By this, SHIP shall be seen as one of the core technologies of a hybrid industrial supply system, well optimized and integrated to the demand.

Whereas "simple" and "reliable" technical and technological solutions are already addressed in the other Subtasks, Subtask E builds upon the remaining aspects of how Solar Process Heat is to be seen by end-users:

- "Innovative": demonstrating that the use of solar thermal technologies in industrial applications is recognized as a potential innovative technological solution for industrial decarbonization; investigate how it is reflected in innovation strategies at regional, national or trans-national levels; fostering the dissemination and use of available research funding for the development of R\&D projects aiming at technology cost reductions and demonstration activities;

- "Affordable": defining suitable indicators enabling a levelled comparison of CAPEX driven investments in SHIP to the OPEX driven investments of competitor technologies (e.g. boilers or heat pumps); gathering updated information and disseminating the technology cost reduction trends; defining suitable energy cost evolution scenarios enabling a due perception of future heat production costs and a quantification of the "hedging effect" of SHIP towards other energy sources; apply the findings to position SHIP as a core part of a hybrid industrial energy system;

- "Profitable": : demonstrating that a "Payback driven" appraisal of SHIP is short sighted as it does not capture the NPV potential of these CAPEX driven investments; gathering updated information and disseminating new trends on SHIP financing models; developing suitable "PPA-like" scenarios demonstrating that SHIP based LCOH is competitive with other (conventional and/or renewable) energy sources; pooling available SHIP financing possibilities among potential project promoters and/or endusers.

Innovation should be mainly driven by industrial development which, however, can be supported through publicly funded research and development, allowing e.g. to include research centres and other support for R\&D. The availability of public research funding can thus be one factor to support further innovation even for "ready-tomarket" technologies at high TRL. Here, innovation can aim at further improvement of technical performance, simplification of integration and application, cost reductions, new materials or processes or any other means of improvement of overall competitiveness.

In most markets, competitiveness of SHIP technologies is challenging while fossil based heat supply remains available at comparably low cost. To support the competitiveness of low carbon technologies, some countries established incentive programs, aiming for SHIP technologies to become affordable and more profitable for industry.

Therefore, as a first deliverable of Subtask E, a collection of research and incentive programs available for SHIP has been performed by the expert group and is reported in the following.

Besides the collection of available programs, some additional aspects have been discussed in the expert group of Subtask $\mathrm{E}$ and are reported here. Based on these discussions, some recommendations are provided. 


\section{Disclaimer:}

The information contained in this report is, by nature of both the type of information and the methodology of information gathering, not exhaustive and represents a snapshot in time at the time of information gathering. We strongly recommend to explicitly search for first-hand and updated information before using information in any way.

The methodology of information gathering is laid out in section 2. Due to the chosen methodology, the information is not exhaustive in terms of the countries with available programs and may be not exhaustive in available programs in the countries listed either. For further details, refer to section 2.

Also with respect to the indicators for the state of implementation of SHIP and the database used for this, the data is not exhaustive in several respects. For details, see description and discussion in section 4.1.

Received answers reflect the expert knowledge of the contributing experts. Thus, the listed information may not be exhaustive, and does not reflect any official statement by a government or national agency or any other body.

Yet, despite being a non-exhaustive snapshot, the results reported here may be used as indicator of countries and programs, or at least as additional source of search terms (funding bodies or agencies, program names, ...) to look for updated and first-hand information.

\subsection{Executive Summary}

Solar Heat for Industrial Processes (SHIP) is a ready-to-market technology that can provide renewable heat to industry. Subtask E "Guideline to Market" of the Task 64/IV "Solar Process Heat" aims to support faster and broader market rollout by demonstrating that SHIP technologies are innovative, affordable and profitable.

To accelerate innovation and improve competitiveness, programs and instruments of public funding and incentives can be issued, supporting the objectives of Subtask E. To disseminate opportunities provided by such instruments, Subtask $E$ therefore initiated a survey on available funding programs for SHIP related research and on funding/incentive programs and instruments for SHIP installations.

In a survey amongst experts involved or connected to Task 64/IV Solar Process Heat, available incentives for SHIP installations and research funding programs from 18 countries (out of 32 countries approached in total) have been collected and are provided in this report.

The funding programs for SHIP installations use different incentive types like a grant on investment, tax exemptions, loan programmes or others. The incentive type used most amongst the received answers is a direct grant on initial investment of SHIP plants (in place in 9 countries), followed by advantageous taxation of even tax exemptions (8) and loan programmes (6). In 5 countries, other types of incentives are installed.

A comparison of the availability of funding programs to the status of SHIP implementations in the investigated countries, represented by the number of plants and the total installed gross collector area as retrieved from the SHIP projects database www.ship-plants.info, allowed for a qualitative check whether a broad SHIP rollout is correlated to the availability of funding programs. As a result, in those countries showing the most advanced SHIP rollout, funding instruments are available. However, the availability of funding instruments alone seems not sufficient for a successful broad SHIP rollout.

Based on the results of the survey, the subsequent analysis of the feedback and discussions in the Subtask, the expert group active in Task 64/IV "Subtask E: Guideline to Market" recommends incentive/funding instruments to support the faster and broader market rollout of SHIP technologies. Based on the feedback of relevant technology suppliers within the Subtask E expert group, direct subsidies on initial investment for SHIP installation (CAPEX) are the preferred option of funding/incentive programmes as it is easiest to include in an economic assessment approach, for communication with end users and by this, to support actual implementation including financing. But as diverse SHIP plants are, as important are specific solutions for all relevant stakeholders along the different project phases including the industrial end-users, the technology suppliers but also plant operators and investors. This is further discussed in this report. 


\section{Methodology}

In the following sections, the methodology applied to gather the information presented in this report is briefly described. The main concept of information gathering was based on the expert group active in Task 64/IV. Experts were approached and asked for contributions referring to their "home" country by means of standardised basic information entered into a template. This information gathering was iterated several times to increase the number of responses. All responses were collected and evaluated.

\subsection{Scope of countries}

Experts from 32 countries are listed to participate in Task 64/IV. As the information gathering relied on contributions from experts, the countries included in the information gathering activities correspond to the "home" countries of the Task 64/IV expert list. These are listed in the following Table 1.

Table 1: List of countries where experts were approached (in alphabetic order)

\begin{tabular}{l|l|l|l|}
\hline Argentina & Denmark & Ireland & South Africa \\
\hline Australia & Ethiopia & Italy & Spain \\
\hline Austria & Finland & Korea & Sweden \\
\hline Belgium & France & Mexico & Switzerland \\
\hline Brazil & Germany & Morocco & The Netherlands \\
\hline Canada & Greece & Namibia & UK \\
\hline Chile & Hungary & North Macedonia & Uruguay \\
\hline China & India & Portugal & USA \\
\hline
\end{tabular}

Since we did not receive responds from all contacted experts / countries, the results presented below may refer only to a smaller number of countries from which responses were received, see details listed with the results.

\subsection{Collection of information}

In a first round, one expert from each country was chosen and contacted via E-mail, asking for support and information feedback. Several reminders have been sent out, and where no responses were received, another expert from the respective country was contacted. The contacting and communication to experts was mostly done by E-mail exchange.

Received answers reflect the expert knowledge of the contributing expert. Thus, the listed information may not be exhaustive, and does not reflect any official statement by a government or national agency or any other body.

Interim status of information gathering was reported together with the interim results during several Task 64/IV expert meetings and Subtask E meeting, together with the request to participating experts to provide information on countries where no feedback had been received so far.

The results were collected in an MS EXCEL spreadsheet which has been made available to the Subtask E expert group through a joint cloud drive of the Subtask.

\subsection{Type of information and information processing}

It should be noted that the request for information on programs was explicitly addressing all programs where SHIP research or SHIP projects could apply to. These may be not SHIP specific programs, but also rather broader programs e.g. on renewable energy integration or innovations in industry. Despite the fact that this had been communicated repeatedly, some responses received stated that in a requested category « no SHIP specific instruments / programs were available ».

Furthermore, all approached experts had been asked to provide also information if no programs are known to be 
available, thus providing a negative answer. Nevertheless, only answers were received from countries where one or the other program/instrument or both was available.

Information was collected in two main categories, namely

- Information on available SHIP related research programs

Programs offering public funding for SHIP related research, development and demonstration projects.

- Information on available SHIP related funding/incentive programs

Programs offering incentives for the implementation of SHIP projects and installations. Since different types and concepts of incentives are available, the type of incentive was retrieved as well.

For more details, see Sections 3.1.2. and 3.3.

For the evaluation of the results, the status of SHIP implementation in the investigated countries was retrieved from the SHIP projects database www.ship-plants.info, maintained by AEE - Institute for Sustainable Technologies (AEE INTEC), Austria. This database was an output of the IEA SHC Task49.

Interim results and final results have been presented to the expert group in Task and Subtask E expert meetings and discussed with respect to the experiences and recommendations. For more details, see Chapter 5.

\section{Collection of available research and funding/incentive programs}

\subsection{Collected information}

For each country where feedback was received, the detailed information is provided in the Annex. The information contains the following categories (where applicable / available):

\subsubsection{Funding/incentive program}

Name of Funding Program: Specific name of the funding program / instrument available for SHIP funding

Funding institution: Public bodies and/or agencies providing the funding and/or involved in the funding process

Funded technology: Technologies addressed by the funding instrument

Funded sector / beneficiaries: Industrial sector or group of beneficiaries addressed by the funding instrument

Instrument type: Type of funding instrument - see section 3.1 .2

Incentive (quantitative): If available, quantitative information on the funding (e.g. \% of CAPEX)

Conditions/requirements: Requirements, prerequisites and conditions to qualify for this instrument

Duration / expiry date: Duration of the instrument / program

Source / Reference (for details): A direct reference to the primary source describing this instrument, e.g. Weblink / URL.

Last update, provided by: source and date of last entry

\subsubsection{Type of Funding/incentives}

Subsidies / CAPEX: Direct subsidy on initial investment (capital expenditure, CAPEX) for SHIP investments or cost related to SHIP installations 
Loan: Loans, typically provided under advantageous conditions, for SHIP investments or cost related to SHIP installations

Taxation: Tax exemption or tax abatement for SHIP investments or cost related to SHIP installations

Services: Support / Grant / Subsidy for services related to SHIP installations, e.g. Energy Audits, Planning/Engineering support, Consultancy, ....

OPEX / Generated heat: Feed in Tariffs, subsidized heat supply, ...

Others: Support for Contracting, issue of certificates, vouchers, or any other type of support (contributors were asked to please specify / provide some info on the specific type of instrument)

Research funding: Partial or full coverage / support of research activities on SHIP related topics, including demonstration projects

\subsection{Overview on available funding programs for SHIP related RTD and funding/incentive programs for SHIP installations}

Of 32 countries approached, 18 answers were received. The following table gives an overview on the availability of programs/instruments.

Table 2: List of countries where answers on the (non-/)availability of programs/instruments was received (18 of 32 approached, in alphabetic order). Green indicates availability of programs, Yellow indicates that no program is available. No feedback was received from Argentina, Australia, Belgium, Canada, China, Ethiopia, Finland, Hungary, Ireland, Korea, Namibia, North Macedonia, Switzerland and the Netherlands.

\begin{tabular}{|c|c|c|c|}
\hline & & & RTD \\
\hline Country & -1 & Incentive $\mathbf{V}$ & Funding \\
\hline Austria & & $x$ & $x$ \\
\hline Brazil & & $x$ & $x$ \\
\hline Chile & & $x$ & \\
\hline Denmark & & & $x$ \\
\hline France & & $x$ & $x$ \\
\hline Germany & & $x$ & $x$ \\
\hline Greece & & $x$ & $x$ \\
\hline India & & $x$ & $x$ \\
\hline Italy & & $x$ & $x$ \\
\hline Mexico & & $x$ & \\
\hline Morocco & & $x$ & $x$ \\
\hline Portugal & & $x$ & $x$ \\
\hline South Africa & & $x$ & \\
\hline Spain & & $x$ & \\
\hline Sweden & & $x$ & $x$ \\
\hline UK & & $x$ & $x$ \\
\hline Uruguay & & $x$ & $x$ \\
\hline USA & & $x$ & $x$ \\
\hline Total & & 17 & 14 \\
\hline
\end{tabular}

As can be seen, all of the countries where feedback was received do have one or the other type of programs available, or both. This means that no response has been provided by experts not aware of any program in the respective country, even though we had asked also for negative answers (not available). 


\subsection{Overview on available types of funding/incentive programs for SHIP installations}

The following table gives an overview on the types of funding/incentive programs for SHIP installations. For the definition of types, see listing in section 3.1.2.

Table 3: List of types of programs/instruments for SHIP installations (for 18 countries of 32 approached, in alphabetic order). Green indicates availability of programs, Yellow indicates that no program is available. No feedback was received from Argentina, Australia, Belgium, Canada, China, Ethiopia, Finland, Hungary, Ireland, Korea, Namibia, North Macedonia, Switzerland and the Netherlands. The rightmost column indicates "Other" types of instruments, see text.

\begin{tabular}{|c|c|c|c|c|c|}
\hline & CAPEX & & & & \\
\hline Country & -1 Grant & $\nabla$ & Loan $F$ & Taxation $\nabla$ & $\nabla$ \\
\hline Austria & $x$ & & & & \\
\hline Brazil & $x$ & & & & \\
\hline Chile & & & $x$ & & \\
\hline \multicolumn{6}{|l|}{ Denmark } \\
\hline France & $x$ & & & & \\
\hline Germany & $x$ & & $x$ & & \\
\hline Greece & $x$ & & $x$ & $x$ & $x$ \\
\hline India & $x$ & & $x$ & & \\
\hline Italy & $x$ & & $x$ & $\mathrm{x}$ & $x$ \\
\hline Mexico & & & $x$ & $x$ & \\
\hline Morocco & & & & $x$ & \\
\hline Portugal & $x$ & & & & \\
\hline South Africa & & & & $\mathrm{x}$ & \\
\hline Spain & $x$ & & & & \\
\hline Sweden & & & & $x$ & \\
\hline UK & & & & & $x$ \\
\hline Uruguay & & & & $\mathrm{x}$ & $\mathrm{x}$ \\
\hline USA & & & & $x$ & $x$ \\
\hline Total & & 9 & 6 & 8 & - \\
\hline
\end{tabular}

Of the instrument types which provide direct incentives for SHIP installations, the direct subsidy on initial investment ("CAPEX"/Grant - 9) is the most frequently available instrument, followed by taxation (8) and loans (6). Other types of instruments are available in 5 countries (OPEX, Services, Financing instrument support). For more Details, see the complete collection of information in the Annex.

\section{Further evaluations and recommendations}

The collection on availability of incentives and funding for both R\&D and actual SHIP installations was one goal of this collection. Within the expert group of Subtask E, discussions have been initiated whether further conclusions or recommendations could be derived from the results of the collection. The outcome of these discussions and considerations is provided in the following.

\subsection{Relation between available programs and status of SHIP implementation}

For each country where feedback was received, the detailed information is provided in the Annex. Since any public funding and incentive probably has the main goal to support broader market rollout if SHIP (or, depending on the scope of funding instrument) e.g. renewable technologies in general. Therefore, one interesting question is whether the availability of SHIP incentives does show in the degree of market rollout. 
As an indicator of the status of SHIP implementation in the investigated countries, information on existing SHIP installations was retrieved from the SHIP projects database www.ship-plants.info, maintained by AEE INTEC, Austria. There, general information, e.g. total installed collector aperture area or number of SHIP plants are available per country. To account for the different size of the investigated countries, the number of SHIP plants and the total installed aperture area were both normalized to a value per 50 Mio inhabitants, and are shown alongside the availability of incentives and finding programs in the following graphs.

It should be noted that the numbers will not reflect the actual state of implementation of SHIP in a country, e.g. because not all plants may be registered in the database. This is due to unknown implementations worldwide, but also linked to the definition of SHIP (excluding plants that may be accepted in other surveys) and a defined minimum size of plants. To be accepted and registered on the database, a thorough approval process has to be followed. By this some plants may be discouraged to be listed. On the other hand, using this database allows to use one single data source for the comparison of the countries discussed here, while using different (maybe more detailed specific) data bases e.g. specific for single countries may give rise to even more questions with respect to such an evaluation and comparison. See further remarks in the text following Figure 2 below.

Similarly, the availability of funding and incentive programs reflects the current situation, whereas the number of plants and the total installed area are the result of installations in the past, i.e. cumulated over a long time. Nevertheless, both may be used as indicators for a rough and qualitative cross-check whether any obvious correlations may be noticed.

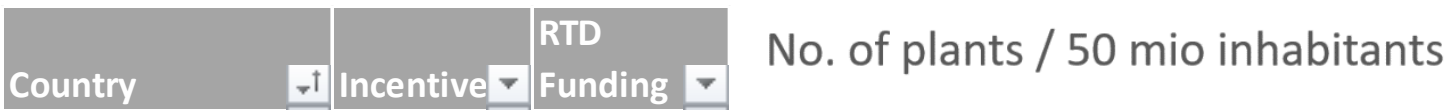

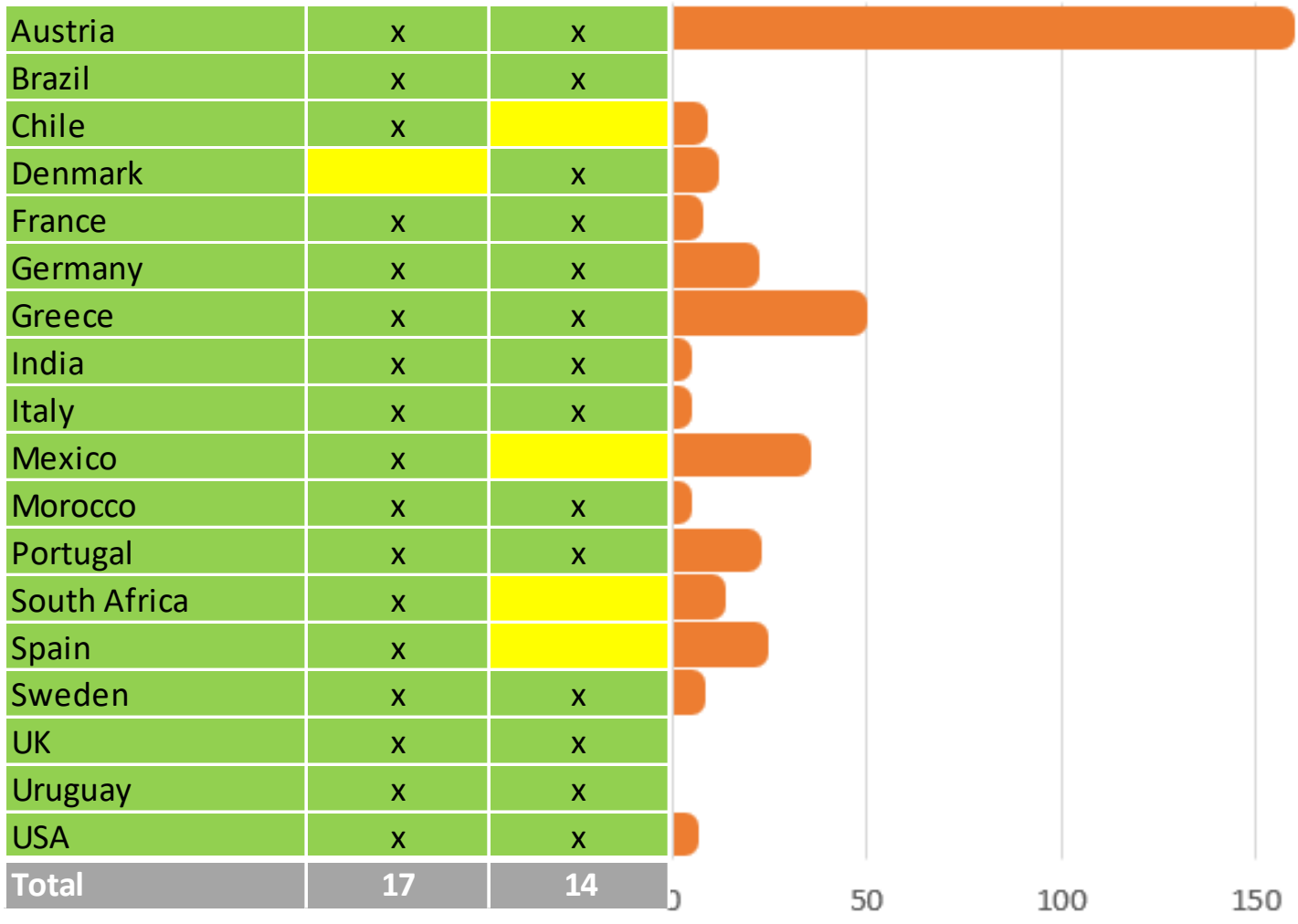

Figure 1: Availability of funding and incentive programs alongside the current status of implementation of SHIP technologies per country. Listed are only countries where answers on incentives/funding was received. As indicator of SHIP implementation, the number of installed SHIP plants per $\mathbf{5 0}$ Mio inhabitants is shown. 


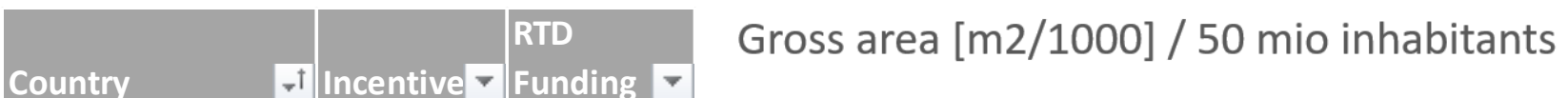

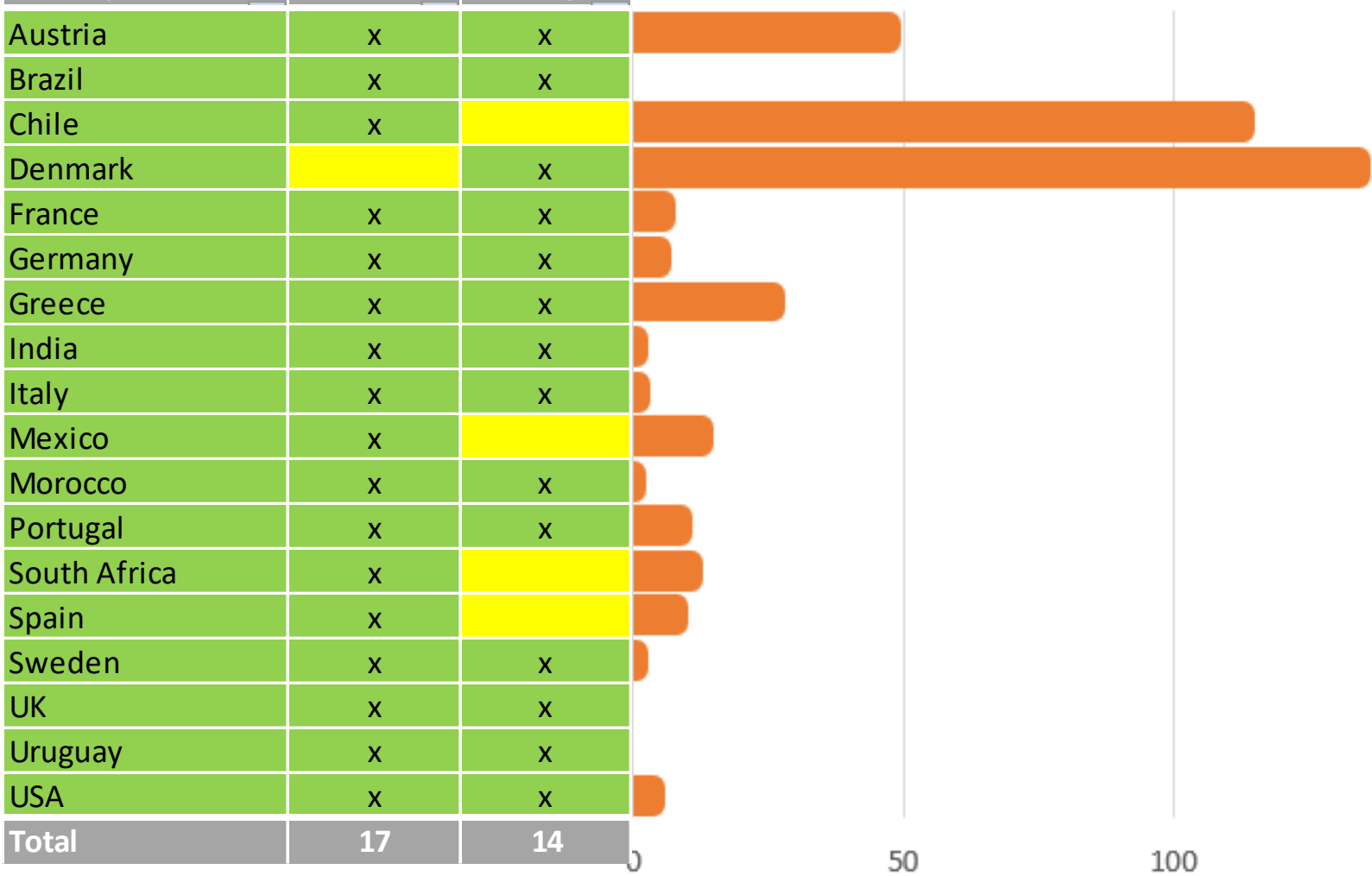

Figure 2: Availability of funding and incentive programs alongside the current status of implementation of SHIP technologies per country. Listed are only countries where answers on incentives/funding was received. As indicator of SHIP implementation, the total gross collector aperture area of installed SHIP plants in $1000 \mathrm{~m}^{2}$ per 50 Mio inhabitants is shown.

From the graphs above, it is obvious that there are a few countries (Austria, Chile, Denmark, Greece) where the status of SHIP implementation seems to be more advanced than in the majority of other countries. The graph also does not take into account what is the number of plants per total installed gross area (example Chile: very large size of one implementation).It should be noted that Mexico has a very high number of existing plants which are, however, obviously not registered in the database used. Similar weaknesses may apply to other countries or absolute numbers. However, we believe that the general conclusions drawn from the evaluation still remain valid even if the used database may be incomplete in some instances.

While a few countries show a very advanced status of implementation (when compared to the other countries yet, on a still rather low level in total absolute numbers), there is no clear correlation between SHIP implementation and availability of funding/incentives. On the other hand, in all countries where SHIP is already more advanced, funding/incentives for either RTD or actual SHIP implementation or both is available.

A similar exercise has been made including all countries approached (all 32 countries). This showed that in none of the countries where no feedback on funding/incentive programs was received (and thus presumably no strong funding/incentive programs exist), the status of implementation is very well advanced if compared to other countries in this survey. 
The fact that there is no clear correlation between the status of SHIP implementation and the availability of funding/incentive programs also indicates that there are many other factors impacting the success and rollout of SHIP. This is in line with results and conclusions found in the EU project INSHIP1.

\subsection{Recommendations}

\subsubsection{Funding/incentive programs}

From the results of this survey, it can be clearly concluded that the availability of incentives for SHIP significantly supports the broader implementation of SHIP technologies. However, the availability of incentives/funding alone is not sufficient, as there are many other factors decisive on the successful market rollout.

With fossil fuels and fossil based heat supply being available at comparatively low cost and through well proven state.of.the.art technologies at usually well known investment cost, competitiveness of solar heat is usually seen challenging and one very important factor in the decision making process of an end user / customer. This is also due to the traditional financial based project assessment via payback driven approaches. Even with unknown development of fuel costs in the future, decisions are often taken based on investment considerations only.

Therefore, the broad majority of experts in Subtask $\mathrm{E}$ recommends the installation of a funding/incentive scheme to support market rollout of SHIP as long as competing heat supply from fossil fueled technologies is comparatively cheap and the cost related to $\mathrm{CO} 2$ emissions remain at a low level.

\subsubsection{Type of funding/incentive program}

The above presented survey results adress funding/incentive programs being one key to a broader market penetration of SHIP plants. A more detailed analysis of available schemes in different countries within this topic highlight that direct subsidies on initial investment for SHIP installation (CAPEX) are a prevalence. This is further supported by the feedback of relevant technology supplier within the Subtask $E$ (expert group of the subtask), naming this support as the preferred option of funding/incentive programmes. Compared to other instruments, this grant is easiest to include in an economic assessment approach, for communication with end users and by this, to support actual implementation including financing. Nevertheless, it is necessary to couple CAPEX driven approaches to constant high-level performance ensuring an optimization along the whole project life-time.

This Deliverable does not have the ambition to assess all available or possible funding schemes and by this create a priority list of most preferred schemes all along the phases of project development, implementation and operation of these systems. As diverse SHIP plants are, as important are specific solutions. Solar Heat for Industrial Processes has to be become a business case for all relevant stakeholders including the industrial endusers, the technology suppliers but also plant operators and investors. Therefore, it will be necessary to further elaborate different schemes tailor-made for these stakeholders. Examples are fundings for project development, funded guarantees for investments, risk management schemes both technical and financial, necessary insurances, but also the development and implementation of legal framework conditions that have to be adapted to the needs of SHIP. This will be further addressed in the activities E2 and E3 within the Subtask E.

\footnotetext{
1 "Report on analysis of needed national and regional innovation strategies on SHIP", - Public Deliverable Report D8.1, August 2019, and "Report on comparative analysis and innovation support roadmaps in Europe" - Public Deliverable Report D8.3, April 2020, of the EC funded Research project INSHIP (Grant Agreement no. 731287).
} 


\section{ANNEX: Detailed results and detailed list of available SHIP RTD funding and SHIP incentives}

\subsection{Detailed results and numbers used in the analysis}

The following table shows the list of all countries and results of the survey and analysis. In the analysis shown in section 4.1, numbers on the status of SHIP implementation extracted from the SHIP projects database www.shipplants.info, maintained by AEE INTEC, Austria, have been used. They have been normalized to an imaginary country size of 50 Mio inhabitants to allow for a comparison of countries. All numbers used in this valuation are listed in the following table. 


\begin{tabular}{|c|c|c|c|c|c|c|c|c|c|c|c|c|c|c|c|c|c|}
\hline & & & & & & & & & & & & & & Incentive & ves type & & \\
\hline & & & & RTD & & & Gross Area & Thermal Power & & & No of plants & gross area per & & CAPEX/ & & & \\
\hline & & Country & it Incentive - & Funding 5 & No of plants & Gross Area[m $\mathbf{V}$ & {$[\mathrm{m} 2] / 1000$} & $\nabla[k W t h]$ & inhabitants & $\checkmark \mathrm{inh} / 50 \mathrm{mio}$ & per50 mio & $50 \mathrm{mio}$ & Country & Grant . & $\nabla$ Loan $V$ & Taxation & $1 \ldots$ \\
\hline 1 & & Argentina & & & 1 & 737.00 & 0.74 & 477.40 & $44,938,712$ & 0.89877424 & 1.11 & 0.82 & Argentina & & & & \\
\hline 2 & & Australia & & & & & 0.00 & & $25,713,700$ & 0.51427400 & 0.00 & 0.00 & Australia & & & & \\
\hline 3 & 1 & Austria & $x$ & $\mathrm{x}$ & 28 & $8,450.80$ & 8.45 & $5,126.63$ & $8,935,112$ & 0.17870224 & 156.69 & 47.29 & Austria & $\mathrm{x}$ & & & \\
\hline 4 & & Belgium & & & & & 0.00 & & $11,492,641$ & 0.22985282 & 0.00 & 0.00 & Belgium & & & & \\
\hline 5 & 1 & Brazil & $\mathrm{x}$ & $\mathrm{x}$ & & & 0.00 & & $210,147,125$ & 4.20294250 & 0.00 & 0.00 & Brazil & $\mathrm{x}$ & & & \\
\hline 6 & & Canada & & & 2 & $1,572.00$ & 1.57 & 846.00 & $38,005,238$ & 0.76010476 & 2.63 & 2.07 & Canada & & & & \\
\hline 7 & 1 & Chile & $\mathrm{x}$ & & 2 & $39,740.00$ & 39.74 & $25,164.74$ & $17,574,003$ & 0.35148006 & 5.69 & 113.06 & Chile & & $\mathrm{x}$ & & \\
\hline 8 & & China & & & 13 & $53,135.70$ & 53.14 & $24,393.36$ & $1,400,050,000$ & $\begin{array}{l}0 \\
0\end{array}$ & 0.46 & 1.90 & China & & & & \\
\hline 9 & 1 & Denmark & & $\mathrm{x}$ & 1 & $15,680.00$ & 15.68 & $9,880.00$ & $5,837,213$ & 0.11674426 & 8.57 & 134.31 & Denmark & & & & \\
\hline 10 & & Ethiopia & & & & & 0.00 & & $109,224,414$ & 2.18448828 & 0.00 & 0.00 & Ethiopia & & & & \\
\hline 11 & & Finland & & & & & 0.00 & & $5,528,737$ & 0.11057474 & 0.00 & 0.00 & Finland & & & & \\
\hline 12 & 1 & France & $\mathrm{x}$ & $\mathrm{x}$ & 6 & $7,471.00$ & 7.47 & $4,630.88$ & $67,081,000$ & 1.34162000 & 4.47 & 5.57 & France & $\mathrm{x}$ & & & \\
\hline 13 & 1 & Germany & $\mathrm{x}$ & $\mathrm{x}$ & 31 & $7,845.70$ & 7.85 & $3,984.52$ & $83,166,711$ & 1.66333422 & 18.64 & 4.72 & Germany & $\mathrm{x}$ & $x$ & & \\
\hline 14 & 1 & Greece & $\mathrm{x}$ & $x$ & 10 & $5,553.00$ & 5.55 & $3,515.72$ & $10,724,599$ & 0.21449198 & 46.62 & 25.89 & Greece & $x$ & $x$ & $\mathrm{x}$ & $\mathrm{x}$ \\
\hline 15 & & Hungary & & & & & 0.00 & & $9,769,526$ & 0.19539052 & 0.00 & 0.00 & Hungary & & & & \\
\hline 16 & 1 & India & $\mathrm{x}$ & $\mathrm{x}$ & 47 & $18,882.20$ & 18.88 & $6,230.03$ & $1,352,642,280$ & $\begin{array}{l}0 \\
0\end{array}$ & 1.74 & 0.70 & India & $\mathrm{x}$ & $x$ & & \\
\hline 17 & & Ireland & & & & & 0.00 & & $6,572,728$ & 0.13145456 & 0.00 & 0.00 & Ireland & & & & \\
\hline 18 & 1 & Italy & $\mathrm{x}$ & $x$ & 2 & $1,178.00$ & 1.18 & 544.00 & $60,317,116$ & 1.20634232 & 1.66 & 0.98 & Italy & $x$ & $x$ & $\mathrm{x}$ & $\mathrm{x}$ \\
\hline 19 & & Korea & & & & & 0.00 & & $51,709,098$ & 1.03418196 & 0.00 & 0.00 & Korea & & & & \\
\hline 20 & 1 & Mexico & $x$ & & 83 & $32,698.60$ & 32.70 & $14,154.05$ & $128,649,565$ & 2.57299130 & 32.26 & 12.71 & Mexico & & $x$ & $\mathrm{x}$ & \\
\hline 21 & 1 & Morocco & $\mathrm{x}$ & $\mathrm{x}$ & 1 & 110.00 & 0.11 & 61.00 & $37,112,080$ & 0.74224160 & 1.35 & 0.15 & Morocco & & & $\mathrm{x}$ & \\
\hline 22 & & Namibia & & & & & 0.00 & & $2,746,745$ & 0.05493490 & 0.00 & 0.00 & Namibia & & & & \\
\hline 23 & & North Macedonia & & & & & 0.00 & & $2,077,132$ & 0.04154264 & 0.00 & 0.00 & North Macedonia & & & & \\
\hline 24 & 1 & Portugal & $x$ & $x$ & 4 & $1,836.00$ & 1.84 & 873.89 & $10,295,909$ & 0.20591818 & 19.43 & 8.92 & Portugal & $\mathrm{x}$ & & & \\
\hline 25 & 1 & South Africa & $\mathrm{x}$ & & 12 & $12,804.20$ & 12.80 & $7,800.99$ & $59,622,350$ & 1.19244700 & 10.06 & 10.74 & South Africa & & & $\mathrm{x}$ & \\
\hline 26 & 1 & Spain & $x$ & & 20 & $7,753.75$ & 7.75 & $4,442.82$ & $47,431,256$ & 0.94862512 & 21.08 & 8.17 & Spain & $\mathrm{x}$ & & & \\
\hline 27 & 1 & Sweden & $\mathrm{x}$ & $\mathrm{x}$ & 1 & 100.00 & 0.10 & 40.00 & $10,367,232$ & 0.20734464 & 4.82 & 0.48 & Sweden & & & $\mathrm{x}$ & \\
\hline 28 & & Switzerland & & & 6 & $2,004.00$ & 2.00 & $1,067.80$ & $8,570,146$ & 0.17140292 & 35.01 & 11.69 & Switzerland & & & & \\
\hline 29 & & The Netherlands & & & 2 & $9,400.00$ & 9.40 & $5,952.40$ & $17,418,808$ & 0.34837616 & 5.74 & 26.98 & The Netherlands & & & & \\
\hline 30 & 1 & UK & $\mathrm{x}$ & $\mathrm{x}$ & & & 0.00 & & $67,886,004$ & 1.35772008 & 0.00 & 0.00 & UK & & & & $\mathrm{x}$ \\
\hline 31 & 1 & Uruguay & $\mathrm{x}$ & $\mathrm{x}$ & & & 0.00 & & $3,518,552$ & 0.07037104 & 0.00 & 0.00 & Uruguay & & & $\mathrm{x}$ & $x$ \\
\hline 32 & 1 & USA & $\mathrm{x}$ & $\mathrm{x}$ & 20 & $24,660.40$ & 24.66 & $10,793.52$ & $328,239,523$ & 6.56479046 & 3.05 & 3.76 & USA & & & $x$ & $x$ \\
\hline & & Total & 17 & 14 & & & & & & & & & Total & & 9 & 8 & 3] \\
\hline & 18 & & & & & & & & & & & & & & & & \\
\hline
\end{tabular}

Table 3: Full detailed list of countries where experts were approached (32, in alphabetic order) and feedback received (18).

Grey indicates: no feedback received; Yellow indicates: feedback received, but no instrument available; Green indicates: instrument available.

Left columns: availability of instruments;

Center columns: indicators for the status of SHIP implementation, extracted from the SHIP projects database www.ship-plants.info, maintained by AEE INTEC, Austria.

Right columns: Listing of incentive type. 


\subsection{SHIP related research funding and funding/incentives programs for SHIP installations}

The detailed collection of all feedback received is annexed by means of an MS-EXCEL file. This file contains

- $\quad$ one spreadsheet on SHIP related RTD funding,

- $\quad$ one spreadsheet on funding/incentives for SHIP installations and

- $\quad$ one sheet listing the funding/incentive types (as also listed in section 3.1.2). 
Incentives (funding/support options)

for solar process heat installations in different countries

Country Program Name

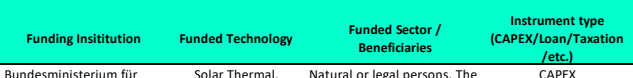
Incentive (quantitative) Brief Conditions/
requirements

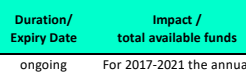
Source / Reference (for details) last update, provided by

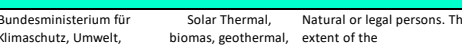

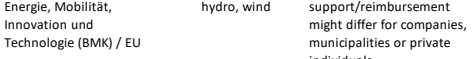

$\overline{\text { Austria }}$ Programme des Klima- und Energieforonds

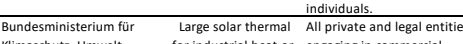

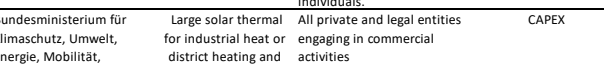
Depends on the size of the instalation. Aid up to Environment-related
$\epsilon 200,00$ over a period of three years. Or
investment costs must AEE, Sept 2020

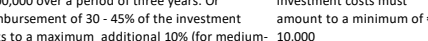

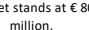
companies.

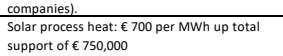

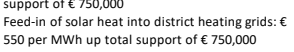

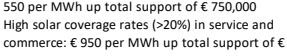
750,000
Combinations of solar ther

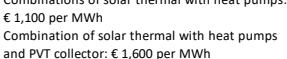

\begin{tabular}{|c|c|c|c|c|c|c|c|c|c|c|c|}
\hline 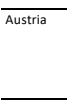 & Speedific to each state & 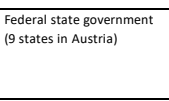 & $\begin{array}{l}\text { Solar, biogas, } \\
\text { geothermal, etc. }\end{array}$ & 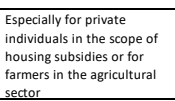 & CAPEXX & Specific to each state & & ongoing & Specific to each state & 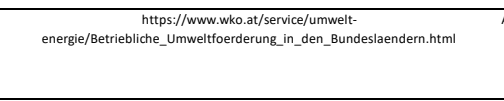 & AEE, Sept 2020 \\
\hline$\overline{B r a z i l}$ & $\begin{array}{l}\text { National Develogment Bank FINAME - Renewable } \\
\text { Energy rogegram }\end{array}$ & $\begin{array}{l}\text { BNDES - National } \\
\text { Development Bank }\end{array}$ & $\begin{array}{c}\begin{array}{c}\text { Renewable energy, } \\
\text { including solar water } \\
\text { heaters }\end{array} \\
\end{array}$ & 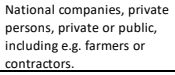 & CAPEX & 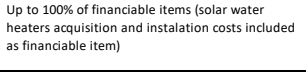 & & ongoing & & 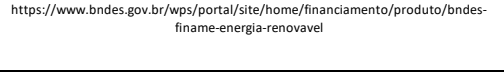 & $\begin{array}{l}\text { September 2020, } \\
\text { LEPTEN/UFSC }\end{array}$ \\
\hline$\overline{\text { Brazil }}$ & $\begin{array}{l}\text { National Development Bank ENEEM- Energy } \\
\text { Efficiency }\end{array}$ & $\begin{array}{l}\text { ENDES5- National } \\
\text { Development Bank }\end{array}$ & $\begin{array}{l}\text { Reduction of energy } \\
\text { demand of processes }\end{array}$ & $\begin{array}{l}\text { National companies and } \\
\text { pubbicsector }\end{array}$ & CAPEX & 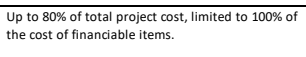 & & ongoing & & 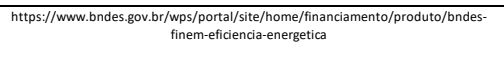 & $\begin{array}{l}\text { September 2020, } \\
\text { LEPTEN/USCC }\end{array}$ \\
\hline $\begin{array}{c}\text { chile } \\
\text { nats }\end{array}$ & 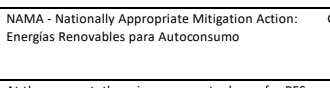 & G11-Chile/ /Energy Ministry & $\begin{array}{l}\text { All renewable energies } \\
\text { for self consumption }\end{array}$ & $\begin{array}{l}\text { Small and medium } \\
\text { companies }\end{array}$ & Lan & N.A. & N.A. & Statrs in 2021 & N.A. & 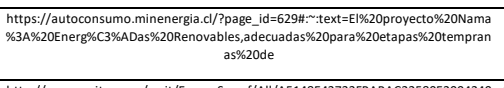 & 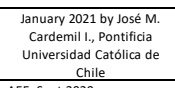 \\
\hline $\begin{array}{c}\text { cyprus } \\
\text {. }\end{array}$ & 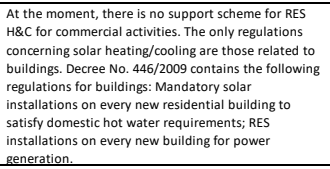 & & & & & & & & & 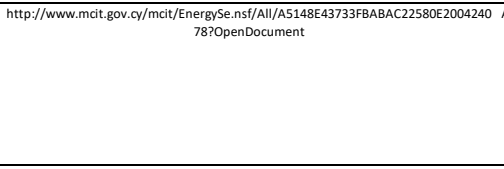 & AEE, Sept 2020 \\
\hline $\begin{array}{c}\text { France } \\
\text { S }\end{array}$ & Fonds chaleur & ADEME & 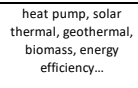 & 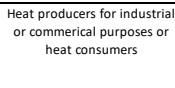 & CAPEX & 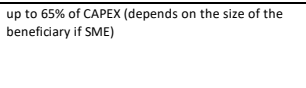 & & ongoing & $350 \mathrm{ME}$ & 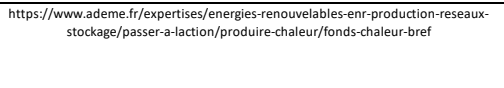 & September, Newheat \\
\hline 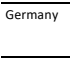 & 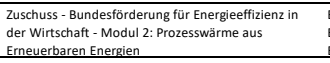 & $\begin{array}{l}\text { BAAA (Federal office for } \\
\text { Exononic Affiris and } \\
\text { Export control) }\end{array}$ & $\begin{array}{c}\text { Solar Thermal, Heat } \\
\text { Pump, Biomass }\end{array}$ &  & CAPEX & $\begin{array}{l}\text { Up to } 55 \% \text { of CAPEX or enlargement of of solar } \\
\text { thermal systems }\end{array}$ & $\begin{array}{l}y=50 \% \text { of produced heat for } \\
\text { industrial processes }\end{array}$ & ongoing & n.a. & 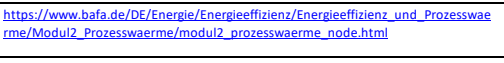 & June 2020, Fraunhoferer ISE \\
\hline Germany & 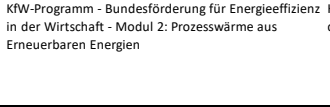 & 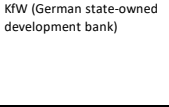 & 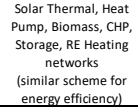 & 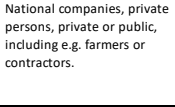 & Laan & 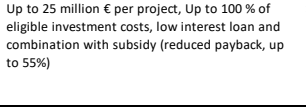 & $\begin{array}{l}\geq=5 \% \text { of produced heat for } \\
\text { industrial processes }\end{array}$ & ongoing & n.a. & 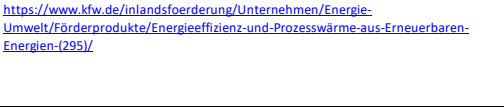 & June 2020, Fraunhofer ISE \\
\hline 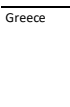 & Development Law (Law 4399/2016) Subsidies & 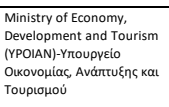 & 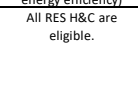 & 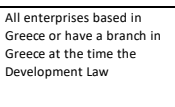 & CAPEX & 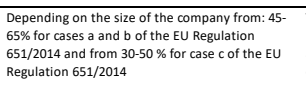 & $\begin{array}{l}\text { To be eligible, the } \\
\text { investment should be > than } \\
\text { a certain ammount depeding } \\
\text { on the size of the company }\end{array}$ & ongoing & & 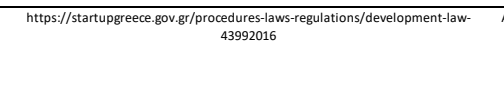 & AEE, Sept 2020 \\
\hline$\overline{\text { Grecece }}$ & Development Law (LLw 439//2016) Tax regulation & $\begin{array}{l}\text { Ministry of Econony, } \\
\text { Developent and Toursm } \\
\text { (vpolan) }\end{array}$ & $\begin{array}{l}\text { All RES HEC are } \\
\text { eligible. }\end{array}$ & 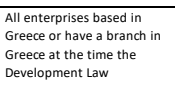 & Taxation & 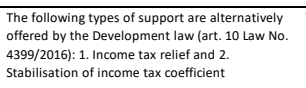 & 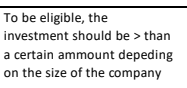 & ongoing & & 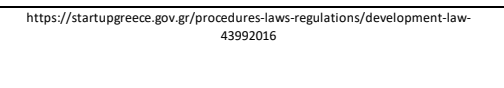 & $\begin{array}{ll}\text { AEE, Sept } 2020 \\
\end{array}$ \\
\hline 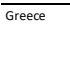 & Law No. 2238//1994 on the Income Tax & $\begin{array}{l}\text { Ministry of Economy, } \\
\text { Developent and Tourism } \\
\text { (Yvolian) }\end{array}$ & $\begin{array}{l}\text { Primarily solar } \\
\text { thermal But al ReS-H } \\
\text { technologies are } \\
\text { eligbie }\end{array}$ & $\begin{array}{l}\text { Natural and leagl persons of } \\
\text { creek nationality and Greek } \\
\text { descent }\end{array}$ & Taxation & $\begin{array}{l}10 \% \text { of the projectct costs may be deduced from } \\
\text { taxable income (up to a maximum of } \mathrm{E} 3,000) \text {. }\end{array}$ & & ongoing & & 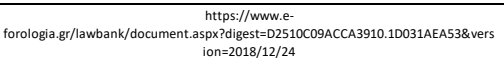 & AEE, Sept 2020 \\
\hline 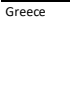 & Development Law (Law 4399/2016) Subsidies & 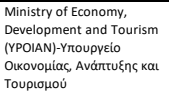 & $\begin{array}{l}\text { Alll RES HiCCare } \\
\text { eligible. }\end{array}$ & 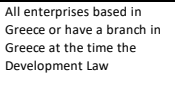 & & 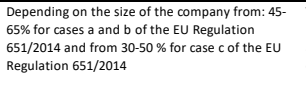 & 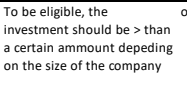 & & & 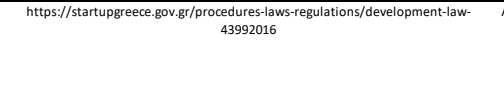 & AEE, Sept 2020 \\
\hline reece & Development Law (Law 4399/2016) Tax regulation & $\begin{array}{l}\text { Ministry of Economy, } \\
\text { Development and Toursm } \\
\text { (Yvolian) }\end{array}$ & $\begin{array}{l}\text { All RES HQC are } \\
\text { eligible. }\end{array}$ & 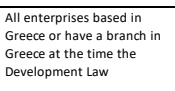 & & 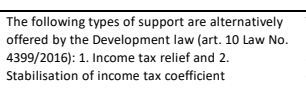 & $\begin{array}{l}\text { To be eligible, the } \\
\text { investment should be > than } \\
\text { a certain ammount depeding } \\
\text { on the size of the company }\end{array}$ & & & 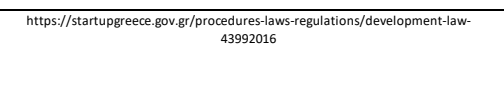 & AEE, Sept t2020 \\
\hline
\end{tabular}




\begin{tabular}{|c|c|c|c|c|c|c|c|c|c|c|}
\hline $\begin{array}{c}\text { Greece } \\
\text { G }\end{array}$ & Law No. 2238/1994 on the Income Tax & $\begin{array}{l}\text { Ministro of Econony, } \\
\text { Development and tourism } \\
\text { (prolian) }\end{array}$ & 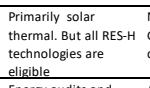 & $\begin{array}{l}\text { Natural and legal persons of Taxation } \\
\text { creek nationality and Greek } \\
\text { desesent }\end{array}$ & $\begin{array}{l}10 \% \text { of the project costs may be deduced from } \\
\text { taxable income (up to to maximum of } \mathrm{f}, 3,000) \text {. }\end{array}$ & & ongoing & & 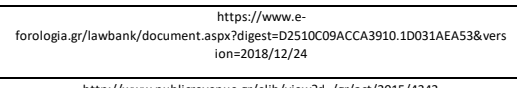 & AEE, Sept 2020 \\
\hline Greece & 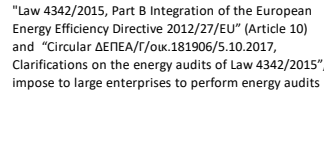 & 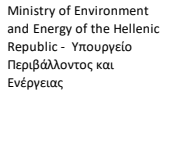 & 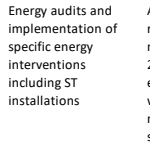 & 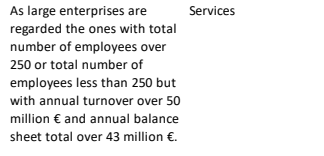 & 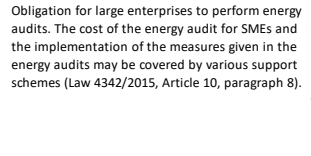 & 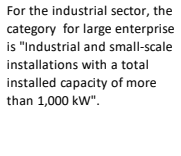 & onging & n.a. & http://Www.publicrevenue.gr/elib/view?d=/g/at/2t/2015/4342 & CRES, Jan 2021 \\
\hline Greece & 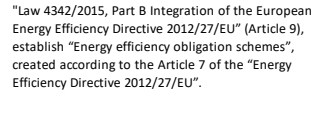 & 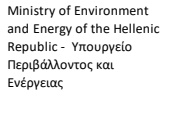 & 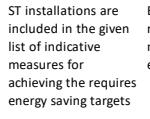 & 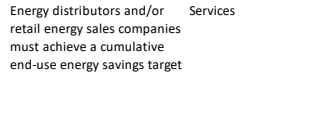 & $\begin{array}{l}\text { Avoiding penaltitis that will be implemented in } \\
\text { case e f fot ret reching the targets }\end{array}$ & & ongoing & n.a. & 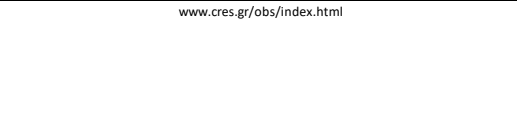 & CRES, Jan 2021 \\
\hline Grecece & 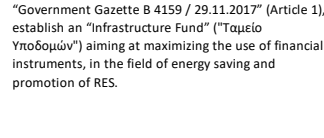 & 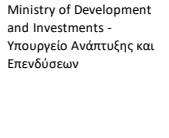 & $\begin{array}{l}\text { ReEs and other } \\
\text { technologies }\end{array}$ & 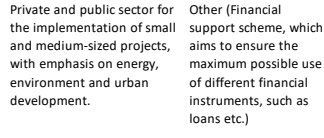 & 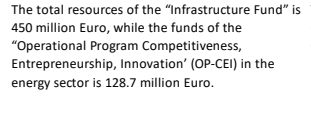 & $\begin{array}{l}\text { The total resources are } \\
\text { distributed to different } \\
\text { Greek Regions. }\end{array}$ & ongoing & n.a. & 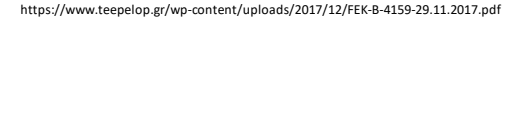 & CRES, Jan 2021 \\
\hline 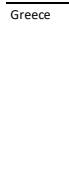 & 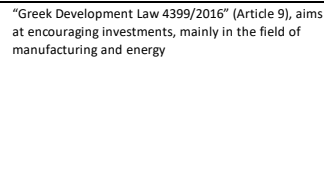 & 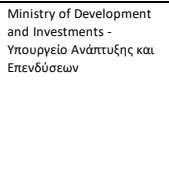 & $\begin{array}{l}\text { RES and other } \\
\text { technologies }\end{array}$ & 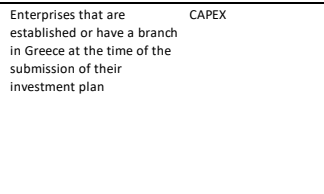 & 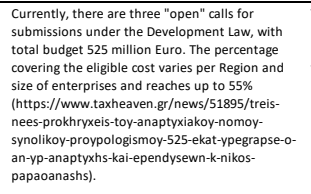 & 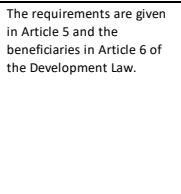 & $\begin{array}{c}\text { ongoing } \\
\mathrm{n}\end{array}$ & $\begin{array}{l}\text { n.a. } \\
\text {. }\end{array}$ & http://lelib.aade.gr/lib/view?d//gr/act/2016/4399/ & CRES, Jan 2021 \\
\hline $\begin{array}{l}\text { India } \\
\text { }\end{array}$ & 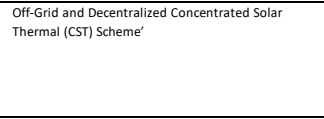 & $\begin{array}{l}\text { Ministry of New and } \\
\text { Renewable Energy (MNRE) }\end{array}$ & Solar thermal & $\begin{array}{l}\text { 光 kind of organization sare } \\
\text { eigible }\end{array}$ & 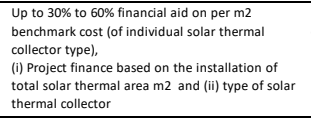 & $\begin{array}{l}\text { No special requirement tor } \\
\text { eligibihty }\end{array}$ & $201-032-20$ & $\begin{array}{c}\text { n.a. } \\
\text {. }\end{array}$ & 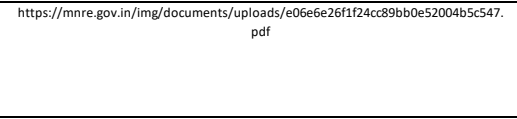 & $\begin{array}{l}\text { September 2020, GERMI } \\
\end{array}$ \\
\hline 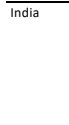 & 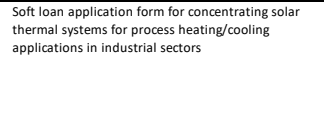 & 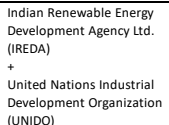 & Solar Thermal & 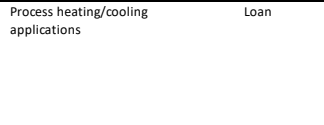 & 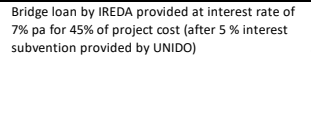 & 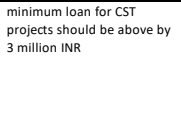 & ongoing & $\begin{array}{ll}\text { n.a. } \\
\text {. }\end{array}$ & 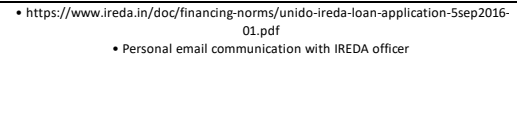 & September 2020, GERMI \\
\hline$\overline{\text { India }}$ & $\begin{array}{l}\text { Ooff-Grid and Decentralized Concentrated Solar } \\
\text { Thermal (CST) Scheme' }\end{array}$ & $\begin{array}{l}\text { Ministry of New and } \\
\text { Renewable Energy (MNRE) }\end{array}$ & Solar Thermal & $\begin{array}{l}\text { all kind of organizations are } \\
\text { eligbie }\end{array}$ & 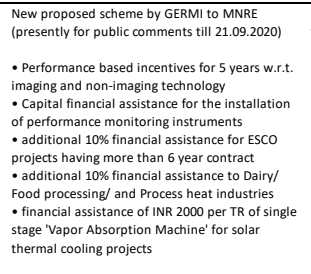 & $\begin{array}{l}\text { - minimum } 160 \mathrm{~m} 2 \text { solar } \\
\text { thermal area tor the } \\
\text { eligibility }\end{array}$ & $\begin{array}{c}\text { under public } \\
\text { comments } \\
\text { (dratt) }\end{array}$ & n.a. & https://mnre.gov:in/img/documents/uploads/file_f-1599462875132.pdf & September 2020, GERMI \\
\hline $\begin{array}{l}\text { tealy } \\
\end{array}$ & Conto Termico & $\begin{array}{l}\text { Ministero dello } \\
\text { sviluppo economic }\end{array}$ & $\begin{array}{l}\text { Small RES-H sources. } \\
\text { Heat pumps, biomass } \\
\text { and solar thermal }\end{array}$ & 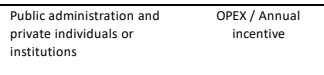 & $\begin{array}{l}\text { Paid annual (2-5 years) incentive in } \ell / / \text { Whith for } \\
\text { each } m \text { 2 of instalded solar area. Depending on the } \\
\text { type and surface of the installation }\end{array}$ & $\begin{array}{l}\text { Installations are elligible } \\
\text { provided that hey yall in } \\
\text { some specific cases }\end{array}$ & ongoing & & 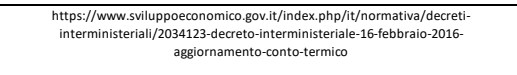 & AEE, Sept 2020 \\
\hline  & 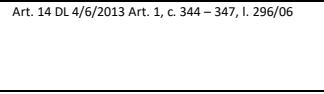 & $\begin{array}{l}\text { Ministero dello } \\
\text { sviluppo economico }\end{array}$ & $\begin{array}{l}\text { Biomass, Aerethermal, } \\
\text { geoothermanand solat r } \\
\text { thermal }\end{array}$ & $\begin{array}{l}\text { 1. Any party ystalling eligible } \\
\text { pants }\end{array}$ & 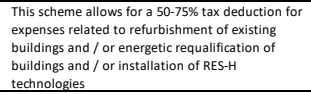 & & ongoing & & 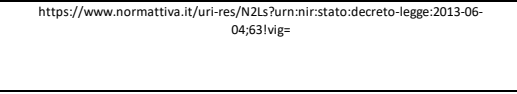 & AEE, Sept 2020 \\
\hline$\overline{\text { Italy }}$ & $\begin{array}{l}\text { Fondo nazionale per I'efficienzza energetica } \\
\end{array}$ & $\begin{array}{l}\text { MISE (Ministero Sviluppo } \\
\text { Economico) }\end{array}$ & 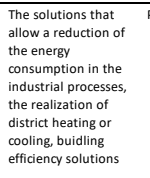 & Private or public & Up to $70 \%$ of the admisisible costs & 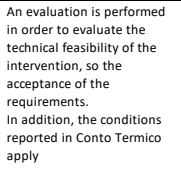 & 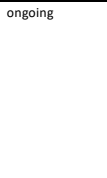 & 310 Me & 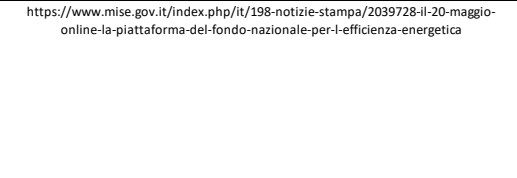 & 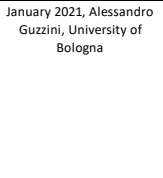 \\
\hline
\end{tabular}




\begin{tabular}{|c|c|c|c|c|c|c|c|c|c|c|c|}
\hline$\overline{\text { Mexico }}$ & Fiscal incentives: Accelerated Depreciation & $\begin{array}{l}\text { Secetetariat of finance and } \\
\text { Public redit }\end{array}$ & Renewable Energy & Private Companies & 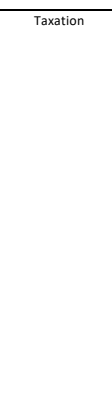 & 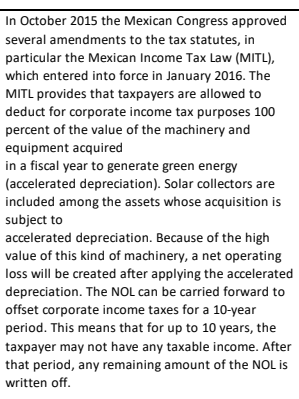 & $\begin{array}{l}\text { Have the equipment } \\
\text { installed torat teast } 5 \text { years }\end{array}$ & ongoing & n.a. & 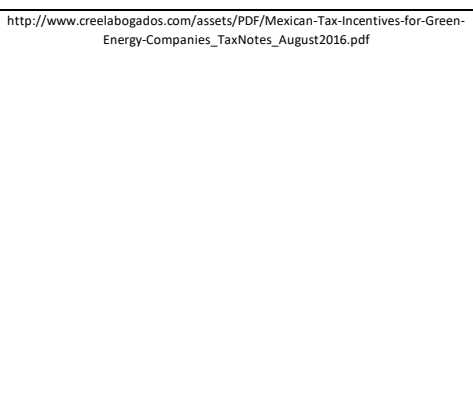 & $\begin{array}{l}\text { September 2020, Inventive } \\
\text { Power }\end{array}$ \\
\hline $\begin{array}{l}\text { Mexico } \\
\text { M }\end{array}$ & FIDE: Energy efficiency & 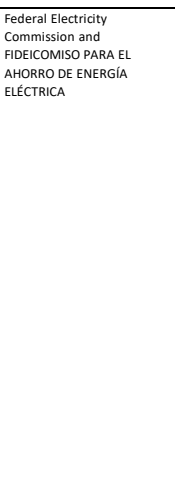 & $\begin{array}{l}\text { Solar, Energy } \\
\text { Efficiency }\end{array}$ & 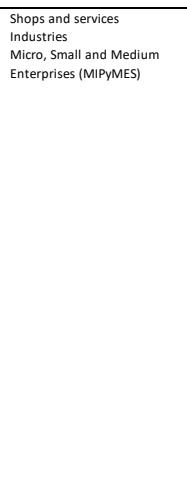 & Laan & 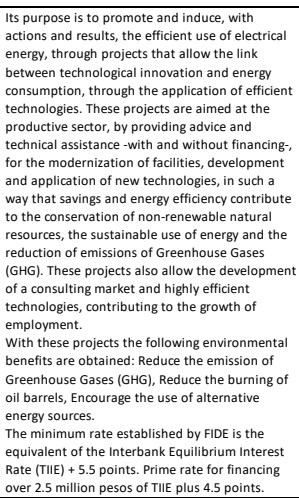 & $\overline{G o o d ~ F i n a n c i n g ~ s c o r e ~}$ & ongoing & n.a. & http:///www.fide.org.,mX/Ppage_idd=17731 & $\begin{array}{l}\text { September 2020, Inventive } \\
\text { Power }\end{array}$ \\
\hline 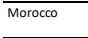 & & & & & axation & partial VAT exoneration on fitat plate collectors & & & & & $\begin{array}{l}\text { Januarr 2021, Green Energy } \\
\text { park }\end{array}$ \\
\hline $\begin{array}{l}\text { Portugal } \\
\mathrm{n}\end{array}$ & 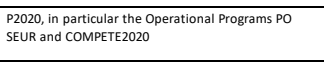 & 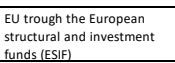 & Generic & $\begin{array}{l}\text { Companies, public } \\
\text { institutions, RRD centers, etc }\end{array}$ & CAPEXX & Depending on call I & n.a. & $\begin{array}{ll}\text { ongoing } \\
\end{array}$ & n.a. & 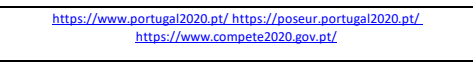 & August 20200, UEvora \\
\hline $\begin{array}{l}\text { Portugal } \\
\mathrm{C}\end{array}$ & 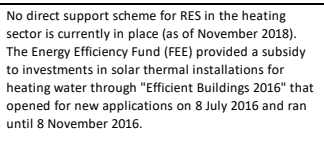 & & & & & & & & & & AEE, Sept 2021 \\
\hline$\frac{\overline{\text { South Africa }}}{}$ & $128 \mathrm{TAX}$ & & Renewable Energy & & Taxation & & 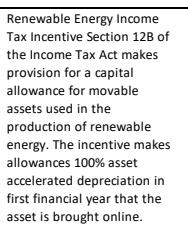 & & & & \\
\hline 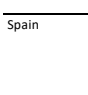 & 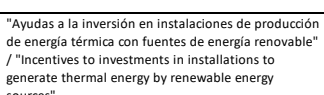 & $\begin{array}{l}\text { DoAf (nstrtitut for } \\
\text { Diversifictiotion and Energy } \\
\text { saving) }\end{array}$ & $\begin{array}{l}\text { Solar thermal, heat } \\
\text { pump powered by } \\
\text { renewable sources, } \\
\text { biomass, goothermal }\end{array}$ & $\begin{array}{l}\text { Public or private companies } \\
\text { and persons }\end{array}$ & CAPEX/grant & 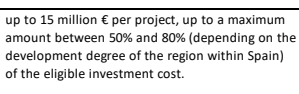 & $\begin{array}{l}\text { General requirements: those } \\
\text { related to EREF (European } \\
\text { Regional Development Fund) }\end{array}$ & $\begin{array}{l}\frac{b}{b} \text { bepened din } \\
0422020\end{array}$ & $\begin{array}{l}110 \text { million EUR for } \\
\text { thermal installations }\end{array}$ & hitps:/www.idae.es/en/node//46672 & $\begin{array}{l}\text { September 2020, Rioglass } \\
\text { Solar }\end{array}$ \\
\hline
\end{tabular}




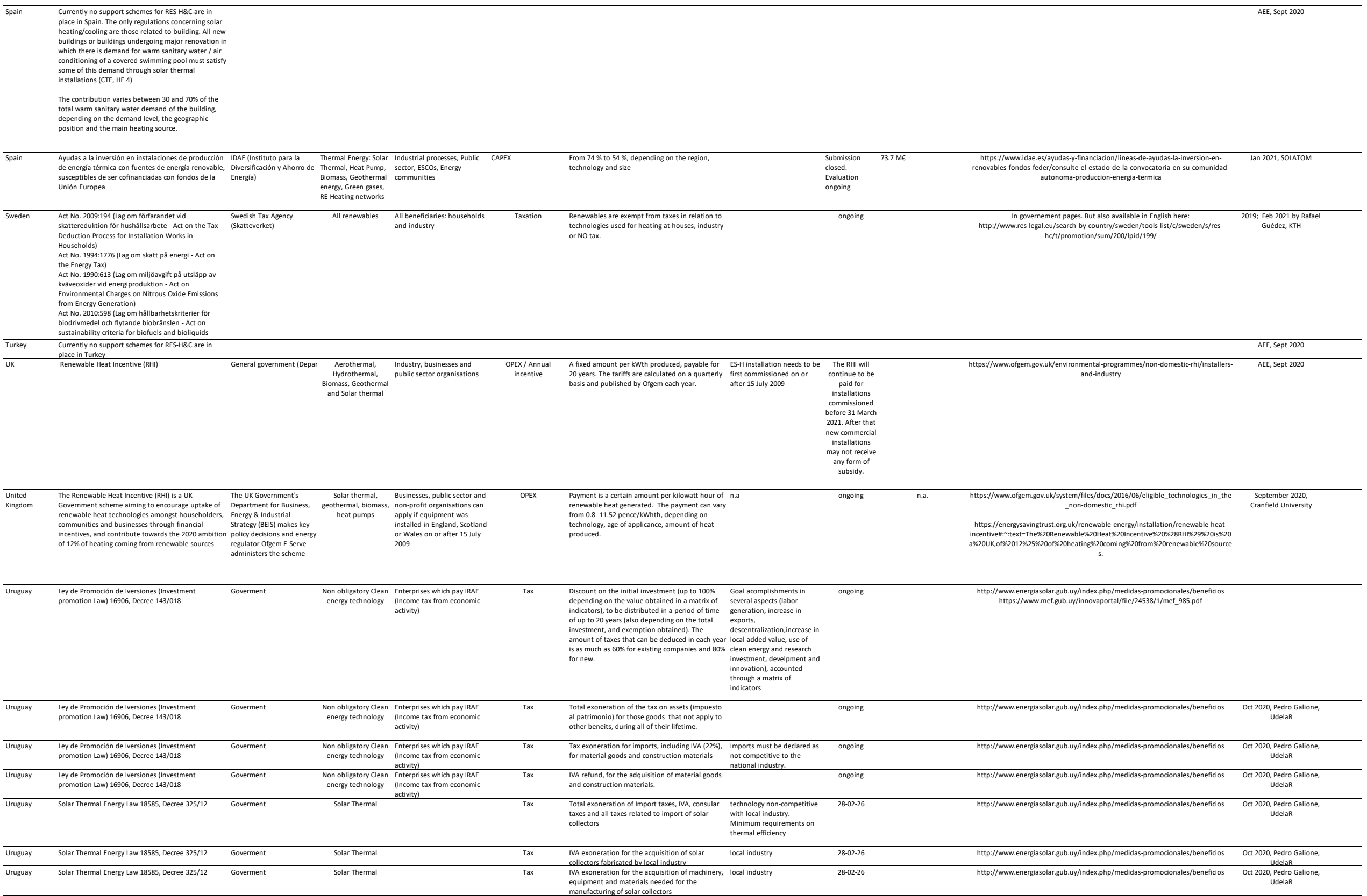




\begin{tabular}{|c|c|c|c|c|c|c|c|c|c|c|c|}
\hline $\begin{array}{l}\text { Uruguay } \\
\text { S }\end{array}$ & 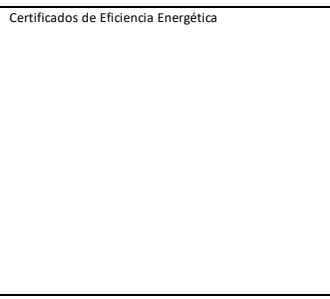 & $\begin{array}{l}\text { Ministry of Industry, } \\
\text { Energy and Mining (MIEM) }\end{array}$ & 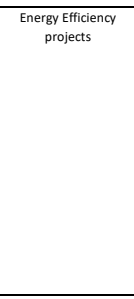 & $\begin{array}{l}\text { energy users or eneregy } \\
\text { service providers }\end{array}$ & 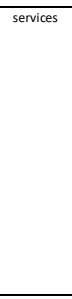 & $\begin{array}{l}\text { Up to } 30 \% \text { of initial investment, through Energy } \\
\text { Efficiencr Certifictes, depending o t the amount } \\
\text { of energy savings in the lifetime of the efficoncy } \\
\text { measure. }\end{array}$ & 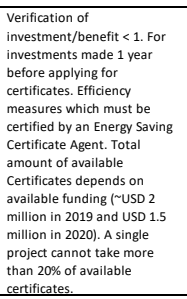 & ongoing & & 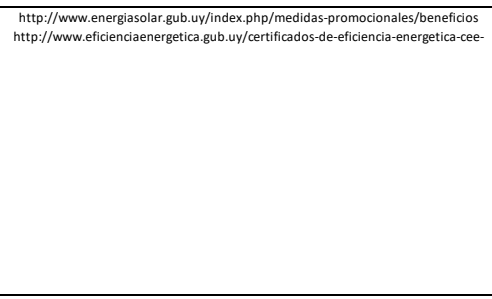 & $\begin{array}{c}\text { Oct 2020, Pedro Galione, } \\
\text { Udelar }\end{array}$ \\
\hline$\overline{U S A}$ & Investment Tax Credit (ITC) & $\begin{array}{l}\text { US Internal Revenue } \\
\text { Services (IRS) }\end{array}$ & 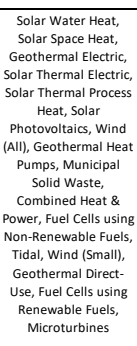 & 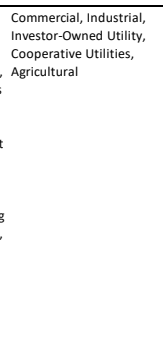 & Taxation & $\begin{array}{l}26 \% \text { Federal tax credit, where there is is reduction } \\
\text { in then inomene taxes paid to the fedecal } \\
\text { government }\end{array}$ & 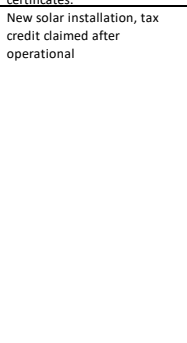 & Ongoing & $\mathrm{NA}$ & hitps://www.rele.gov/doss/fy 180sti/70384.pdf & Sept. 2020, NRELL \\
\hline$\overline{U S A}$ & Modified Accelerated Cost Recovery System (MACRS) & $\begin{array}{l}\text { US Internal Revenue } \\
\text { Services (IRS) }\end{array}$ & 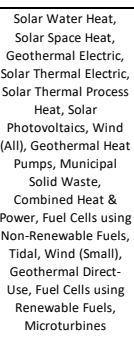 & 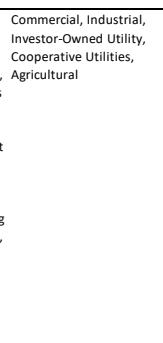 & Financial & 5-7 - years of faccelerated depreciation & New instalatation & Ongoing & $\mathrm{NA}$ & hhtps://www.relel.gov/docs/fy180sti/70384.jpdf & Sept. 2020, NRELL \\
\hline
\end{tabular}




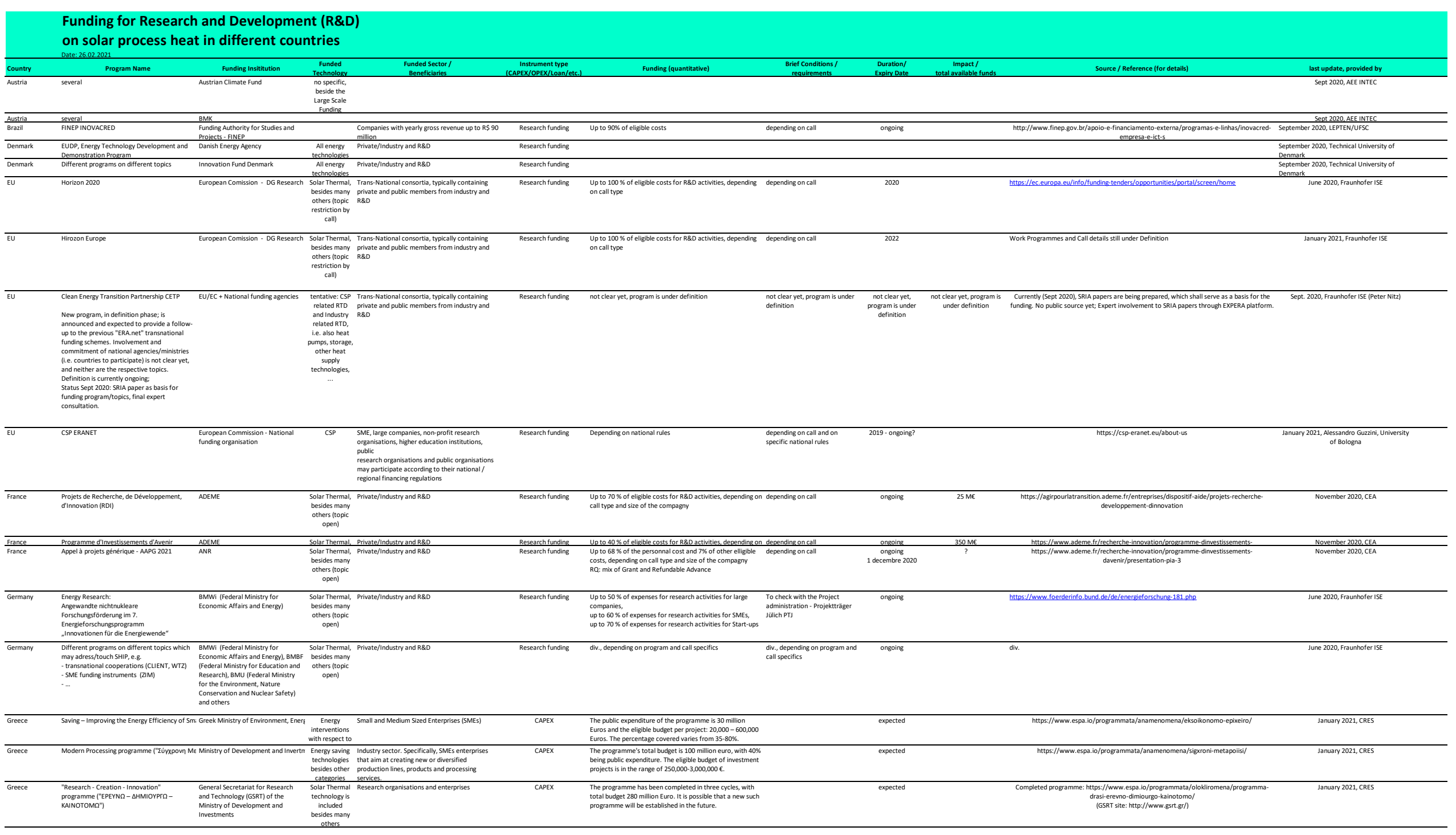


- Improving converision

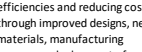

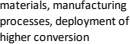

\begin{tabular}{|c|c|c|c|c|c|c|c|}
\hline $\begin{array}{l}\text { Morocco } \\
\text { a }\end{array}$ & Green INNO Project & 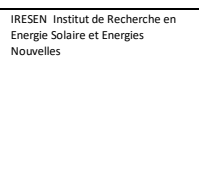 & 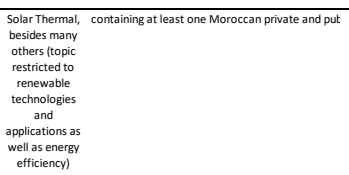 & $\begin{array}{ccc}\text { Research funding } \\
\text {. }\end{array}$ & Upto $100 \%$ of eligible cosst for RRD activities & 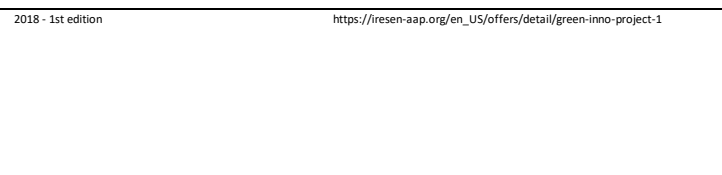 & Januar 2021, Green Energy Pratk \\
\hline 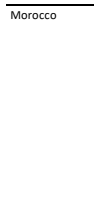 & Green INNo Bosst & 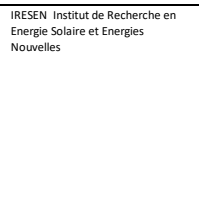 & 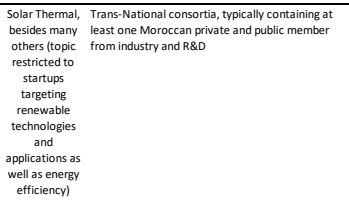 & Reserarch funding & 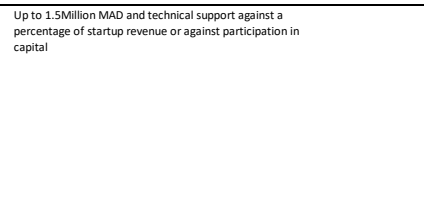 & 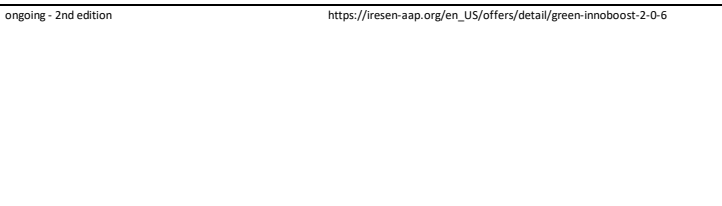 & January 2021, Green Energy Park \\
\hline 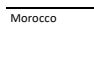 & 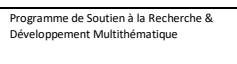 & 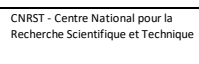 & 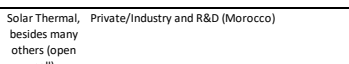 & $\begin{array}{ll}\text { Research funding } \\
\end{array}$ & Up to $100 \%$ of eligible cosst for RBD activities & 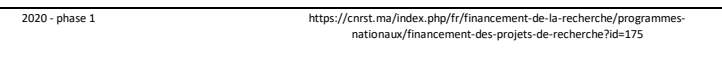 & January 2021, Green Energy Palk \\
\hline$\overline{\text { Morocco/spain }}$ & INNO-ESPAMABOC ENEEGY & RRESENCOTI & 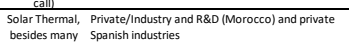 & Reserarch funding & 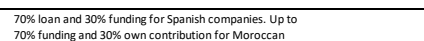 & 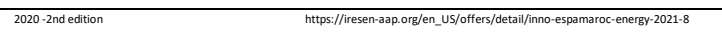 & January 2021, Green Eneresy Park \\
\hline$\frac{\text { Potugal }}{\text { Pons }}$ & P2020 & $\begin{array}{l}\text { EUt trough hhe European structural } \\
\text { andi ivestment tunds (ESIF) }\end{array}$ & 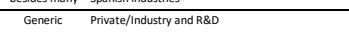 & Research funding & 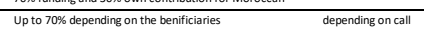 & 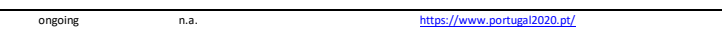 & August 2020, UEvora \\
\hline$\frac{\text { Potugal }}{}$ & $\begin{array}{l}\text { Individual grants and research projects } \\
\text { tutuda }\end{array}$ & 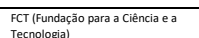 & 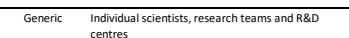 & Research funding & 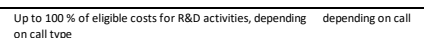 & 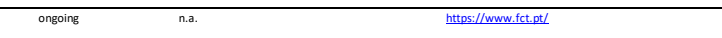 & August 2020, UEvora \\
\hline 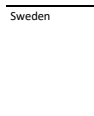 & 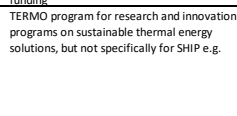 & 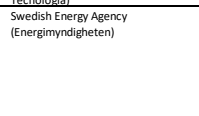 & 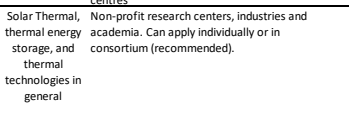 & Research finding & 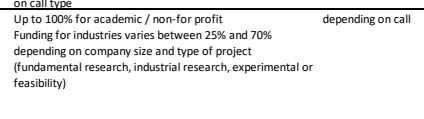 & 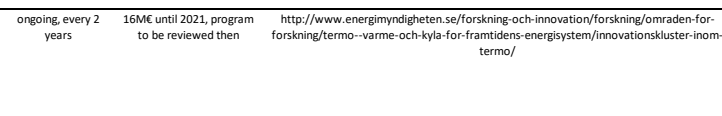 & Dez 19; Feb 2021 by Rafáel Gǘde, KTH \\
\hline 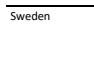 & 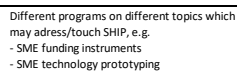 & 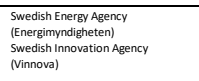 & $\begin{array}{l}\text { Not-specific to Industry } \\
\text { SHHP }\end{array}$ & 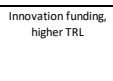 & 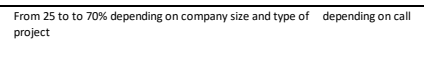 & 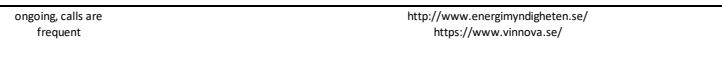 & 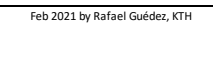 \\
\hline United Kingdom & Imnovate UK & 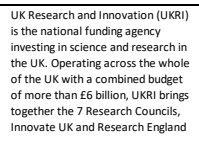 & 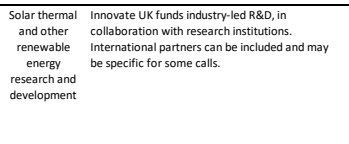 & Research funding & 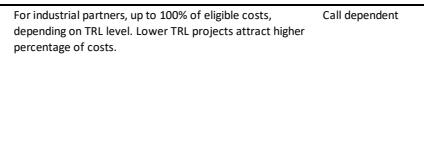 & 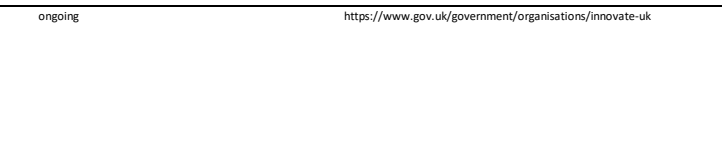 & 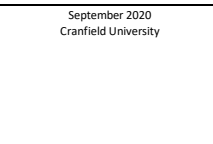 \\
\hline 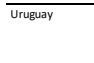 & 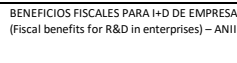 & 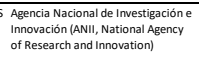 & 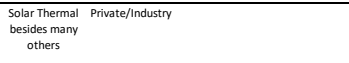 & Research funding & 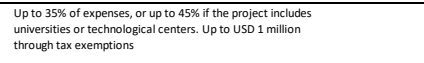 & 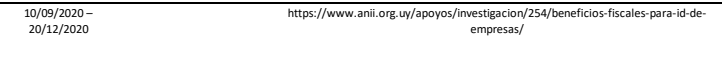 & Oct 2020, Pertro Galione, UdeakR \\
\hline 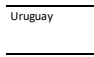 & Several Programs & ANII & $\begin{array}{l}\text { Solar Thermal R8D, private } \\
\text { besises many } \\
\text { other }\end{array}$ & Research tunding & 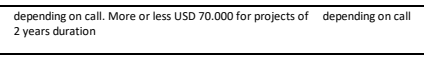 & 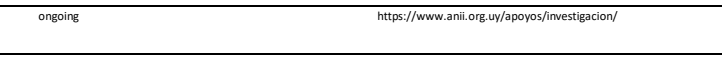 & Oct 2020, Pedro Gallone, UdelaR \\
\hline $\begin{array}{l}\text { usa } \\
\end{array}$ & $\begin{array}{l}\text { American Made Solar Prize - Solar } \\
\text { Desalination }\end{array}$ & 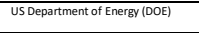 & Solar themermal Priviat//ndustry and RBD & $\begin{array}{l}\text { Prizes } \\
\end{array}$ & $\begin{array}{l}\text { Staged amounts which increase per stage } \\
\end{array}$ & 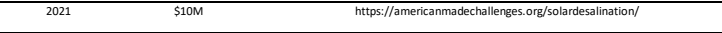 & Sept. 2020, N NEEL \\
\hline
\end{tabular}




\section{Overview on instrument types for SHIP installations}

\section{and SHIP related R\&D incentives and funding instruments}

\begin{tabular}{|c|c|}
\hline Type & Brief description \\
\hline CAPEX & $\begin{array}{l}\text { Financing support, typically covering a certain portion of the } \\
\text { invenstment for a SHIP installation, e.g. through investment grants } \\
\text { or subsidies }\end{array}$ \\
\hline Loan & $\begin{array}{l}\text { Loan with special (typically favouable) credit conditions for SHIP } \\
\text { installations; sometmes combined with partial subsidies }\end{array}$ \\
\hline Taxation & $\begin{array}{l}\text { Special (typically favouable) taxation conditions, tax exemptions } \\
\text { for SHIP installations, or other fiscal instruments }\end{array}$ \\
\hline Services & $\begin{array}{l}\text { Support / Grant / Subsidy for services related to SHIP installations, } \\
\text { e.g. Energy Audits, Planning/Engineering support, Consultancy, .... }\end{array}$ \\
\hline OPEX & Feed in Tariffs, subsidised heat supply, ... \\
\hline Others & $\begin{array}{l}\text { Support for Contracting, issue of certificates, vouchers, or any } \\
\text { other type of support } \\
\text { (please specify / provide some info on the specific type of } \\
\text { instrument) }\end{array}$ \\
\hline Research funding & $\begin{array}{l}\text { Partial of full coverage / support of research activities on SHIP } \\
\text { related topics, including demonstration projects }\end{array}$ \\
\hline
\end{tabular}

